\title{
12/15-Lipoxygenase Expression Is Increased in Oligodendrocytes and Microglia of Periventricular Leukomalacia
}

\author{
Robin L. Haynes ${ }^{a}$ Klaus van Leyen ${ }^{b}$ \\ a Department of Pathology, Boston Children's Hospital and Harvard Medical School, Boston, Mass., and \\ ${ }^{b}$ Neuroprotection Research Laboratory, Department of Radiology, Massachusetts General Hospital and \\ Harvard Medical School, Charlestown, Mass., USA
}

\section{Key Words}

Hypoxia-ischemia - Inflammation · Oxidative stress .

Prematurity $\cdot$ Reactive oxygen species

\begin{abstract}
Oxidative stress involving premyelinating oligodendrocytes $(\mathrm{OLs})$ is a major factor in the pathogenesis of preterm white matter injury. In animal and cell culture studies, activation of the lipid-oxidizing enzyme 12/15-lipoxygenase (12/15-LOX) plays a central role as an inflammatory mediator in the pathology of oxidative stress and OL cell death, as well as ischemia and neuronal death. The role of 12/15-LOX, however, is unclear in the developing human brain. The mechanism of 12/15-LOX involves the production of reactive oxygen species through the metabolism of arachidonic acid, as well as direct detrimental effects on organelle membranes. Here we tested the hypothesis that the density of 12/15-LOX-expressing cells is increased in periventricular leukomalacia (PVL). Using immunocytochemistry (ICC) in human paraffinembedded tissue, 12/15-LOX expression was seen in macrophages of the focally necrotic lesions in the periventricular white matter, as well as in glial cells throughout the surrounding white matter with reactive gliosis. Interestingly, no significant 12/15-LOX expression was detected in neurons in
\end{abstract}

the cerebral cortex overlying the damaged white matter. Using a scoring system from 0 to 3 , we assessed the density of 12/15-LOX-expressing cells in diffusely gliotic white matter from 20 to 43 postconceptional (PC) weeks in 19 PVL cases (median $=36 \mathrm{PC}$ weeks) and 10 control (non-PVL) cases (median $=34$ PC weeks). The density of 12/15-LOX-positive cells was significantly increased in the diffuse component of PVL (score $=1.17 \pm 0.15$ ) compared to controls (score $=0.48 \pm$ $0.21 ; p=0.014)$. Using double-label ICC, 12/15-LOX was observed in PVL in OLs of the $\mathrm{O} 4$ and $\mathrm{O} 1$ premyelinating stages, as well as in mature OLs as determined with the mature OL marker adenomatous polyposis coli (APC). In addition, 12/15-LOX expression was present in a population of CD68positive activated microglia. There was no 12/15-LOX expression in reactive astrocytes. Finally we observed terminal deoxynucleotide transferase dUTP nick end-labeling-positive cells within the white matter of PVL that expressed 12/15-LOX and/or within close proximity of 12/15-LOX-positive cells. Our data support a role for 12/15-LOX activation as an inflammatory mediator of injury in PVL, with a contribution of 12/15-LOX to PVL-induced damage to or cell death of OLs, including those at the $\mathrm{O} 1$ and $\mathrm{O} 4$ stages.

Copyright $\odot 2013$ S. Karger AG, Basel

\section{KARGER}

E-Mail karger@karger.com

www.karger.com/dne (c) 2013 S. Karger AG, Basel

0378-5866/13/0353-0140\$38.00/0
Robin L. Haynes, MD

Department of Pathology, Enders Building, 11th Floor

Boston Children's Hospital, 300 Longwood Avenue

Boston, MA 02115 (USA)

E-Mail Robin.haynes@ childrens.harvard.edu 


\section{Introduction}

The occurrence of brain injury in the human neonate, particularly in the setting of prematurity, is associated with devastating outcomes, including mortality and lifelong neurological deficits. Periventricular leukomalacia (PVL), a lesion of the immature cerebral white matter, is the predominant pathological substrate of the motor and cognitive disorders in long-term survivors of prematurity [1-3]. Pathologically, PVL is composed of a focally necrotic component in the deep periventricular white matter characterized by loss of all cellular elements, and a diffuse component in the surrounding white matter characterized by reactive astrogliosis and microgliosis [4]. While necrotic lesions are still seen at autopsy, with advancements in neonatal care, their pathological features have changed from grossly visible, large cystic cavities, to now smaller, noncavitating focal lesions visible only at the microscopic level and potentially below the level of detection in conventional neuroimaging [5-8]. Of particular interest in PVL is the effect of white matter damage on the developing, premyelinating oligodendrocytes (pre-OLs). In the diffuse component of PVL, damage to pre-OLs is thought to underlie the myelin deficits seen in long-term survivors of prematurity [3]. This is supported by the finding in the human of acute pre-OL loss in PVL [9-11]. While promising therapies are being tested in the human and in animals [12-16], there are currently no drug interventions that completely prevent or ameliorate white matter damage in the premature infant.

The causes of PVL are complex and likely include cerebral ischemia and reperfusion with the contribution of maternal infection with fetal/neonatal systemic inflammation in some cases [2,17-20]. Given its involvement in both hypoxia-ischemia (H-I) and inflammation/infection, a major area of interest in PVL is the role of oxidative stress in the development of white matter injury and OL damage. While evidence of oxidative stress has been shown in PVL $[9,10]$, the sources of reactive oxygen species (ROS) in PVL are currently unknown. One potential source of ROS is 12/15-lipoxygenase (12/15-LOX), which catalyzes the addition of oxygen to arachidonic acid (AA) yielding oxidized derivatives, including hydroperoxyeicosatetraenoic acids. In addition, 12/15-LOX can directly oxidize and damage organelle membranes, causing cell death through mitochondrial injury $[21,22]$. Under conditions of H-I, AA levels in the brain increase due to an increased activation of phospholipase $\mathrm{PLA}_{2}$ which releases AA from cellular membranes [23-26]. In the neonatal rat brain, the RNA encoding leukocyte-type 12-
LOX (the rodent isoform of human 12/15-LOX) is also increased under hypoxic conditions [27], which in the setting of increased AA can result in excessive AA metabolism. Upregulation of $12 / 15$-LOX is an inflammatory response to $\mathrm{H}-\mathrm{I}$ injury and the metabolism of free AA by $12 / 15$-LOX can serve as a source of oxidative stress through the production of unstable byproducts which can function directly as ROS $[28,29]$. In addition to these proinflammatory mediators, $12 / 15$-LOX can, in conjunction with other enzymes, also generate inflammation-limiting lipoxins, resolvins and protectins, which have been proposed to cause resolution of inflammation [30-32]. Besides tissue-damaging effects, protective effects of 12/15-LOX upregulation can thus not be excluded a priori. Interestingly, 12/15-LOX can also directly oxidize AA and other fatty acid substrates esterified as phospholipids resulting in lipid peroxidation of cellular membranes [33, 34].

Important to the role of 12/15-LOX in PVL, under conditions of glutathione depletion, a known consequence of H-I, culture studies have shown that $12 / 15$-LOX activity increases in pre-OLs [35] and that inhibition of 12/15LOX prevents ROS accumulation and pre-OL cell death [35-37]. These animal observations strongly suggest a role for 12/15-LOX in pre-OL damage in PVL, underscoring that inhibition of this enzyme is a therapeutic candidate aimed at the prevention of oxidative stress in PVL in human infants. Prior to the consideration of $12 / 15$-LOX in translational research, however, evidence of the involvement of 12/15-LOX in human PVL must be shown.

In the following study, we examined the expression of 12/15-LOX in PVL in human infants during the second half of gestation. While 12/15-LOX expression has been shown in the human adult brain [38, 39], little is known in regard to 12/15-LOX expression during human brain development or in the setting of human neonatal brain damage. We hypothesized that the density of 12/15-LOXimmunopositive cells is significantly increased in the diffuse component of PVL compared to controls adjusted for age. While we report on findings in both the focal and diffuse lesion, we focused predominantly on the diffuse component, because damage to the diffuse component may result in the global neurological deficits seen in longterm survivors of prematurity [1]. We examined the expression of 12/15-LOX in inflammatory cells of the white matter, i.e. microglia and reactive astrocytes. In addition, we examined 12/15-LOX expression in OLs of the O4 and O1 premyelinating stages in order to determine if this enzyme is upregulated in this vulnerable cell population in association with the inflammatory changes of PVL. 


\section{Materials and Methods}

\section{Clinicopathological Database Information}

Cases were collected from the autopsy services of the Departments of Pathology, Boston Children's Hospital and Brigham and Women's Hospital with parental permission according to the Institutional Review Board protocol. Archival, paraformaldehydefixed, paraffin-embedded brain tissue from either the parietal, occipital, or frontal lobes of 19 PVL cases and 10 controls (i.e. lacking PVL) were used for all single-label immunocytochemistry (ICC) and for all double-label ICC with the exception of O4 and O1 OL immunostaining and deoxynucleotide transferase dUTP nick end-labeling (TUNEL) methodology. In the immunostaining with $\mathrm{O} 4$ and $\mathrm{O} 1$ markers, paraformaldehyde-fixed, non-paraffin-embedded tissue from the parietal-occipital lobes of 5 PVL cases and 4 controls was used. TUNEL staining in combination with 12/15 immunocytochemistry utilized, frozen tissue from the parietal-occipital lobes of 6 PVL and 3 control cases. All cases were classified as PVL or control (non-PVL) by the systematic examination of standardized microscopic sections, stained with conventional hematoxylin-eosin/Luxol-fast-blue, from each brain and spinal cord. As in other studies from our laboratory [9, $40,41]$, PVL was defined as a lesion of the immature cerebral white matter with focal and diffuse components in combination (see above). The control cases were defined as perinatal deaths in which neuropathological examination did not reveal PVL; in these cases, there were no or minimal neuropathological changes in the white and gray matter.

\section{Single-Label ICC}

An affinity-purified polyclonal anti-12/15-LOX antibody raised in rabbits was used [42]. Standard methods in deparaffinized tissue sections $(5 \mu \mathrm{m})$ were performed. Briefly, antigen retrieval involved $10 \mathrm{~min}$ of microwave at $90^{\circ} \mathrm{C}$ in citrate buffer, $\mathrm{pH}$ 6.0. After retrieval, sections were treated with a dual endogenous enzyme block (Dako, Carpinteria, Calif., USA) to inhibit endogenous peroxidase activity followed by a 1-hour protein block in phosphate-buffered saline (PBS) with $4 \%$ normal goat serum. Sections were incubated overnight at $4{ }^{\circ} \mathrm{C}$ in primary antibody diluted 1:200 in protein block solution. After sections had been washed in PBS $+0.1 \%$ Tween 20, biotinylated goat anti-rabbit secondary antibody (Vector Laboratories, Burlingame, Calif., USA) was applied at 1:200 dilution for $30 \mathrm{~min}$ at room temperature. Sections were washed and incubated for $30 \mathrm{~min}$ in $\mathrm{ABC}$ reagent (Dako) followed by diaminobenzidine (DAB) detection. Negative controls omitted the primary antibodies.

\section{Grading Method for Single-Label ICC}

Grading of the cell density (positive cells per high-power field, HPF) of single-labeled tissue sections was performed in both PVL and control tissue, as previously reported by us [9, 40, 41]. After a survey of the entire section, immunopositive cells per HPF (magnification $\times 40$ ) were counted in 3-5 fields within the most intensely stained area of tissue within the periventricular white matter. The 3 fields were averaged and given an overall standardization score as follows: $0=$ no cell staining; $0.5=0-1$ immunopositive cells/HPF; $1=2-10$ cells/HPF; $2=11-20$ immunopositive cells/ HPF; $3=>20$ cells/HPF. Only cells with a well-defined nucleus and 12/15-LOX-stained cytoplasm were counted as positive. Cells with nuclear-only staining were not considered in this quantitative analysis. In PVL cases, the quantitated fields were in the diffuse component only; the focal necrotic lesion was not included in any scoring. Given the obvious nature of white matter pathology in PVL, it was not possible to score 12/15-LOX-immunopositive cells blinded to diagnosis.

\section{Double-Label ICC in Paraffin-Embedded Tissue}

Antigen retrieval was performed as described above in 4-12 PVL cases. Tissue was blocked in PBS containing 5\% goat serum and $0.05 \%$ Triton $\mathrm{X}-100$ for $1 \mathrm{~h}$ at room temperature, and incubated overnight at $4{ }^{\circ} \mathrm{C}$ in blocking solution containing antibodies to $12 / 15$-LOX and one of the following monoclonal antibodies: astrocytic marker glial fibrillary acidic protein (GFAP, 1:5,000; Covance, Princeton, N.J., USA), microglial marker tomato lectin (1:200; Vector Laboratories), activated microglial marker CD68 (1:25; Cell Marque, Rocklin, Calif., USA), or mature OL marker adenomatous polyposis coli (APC, 1:25; Millipore, Billerica, Mass., USA). After a series of washes, the tissue was incubated in blocking solution containing Alexa-Fluor goat anti-rabbit 488 and AlexaFluor goat anti-mouse 590, both at a concentration of 1:1,000 (Molecular Probes, Eugene, Oreg., USA). Immunofluorescence was visualized with the Olympus BX51 microscope (Olympus America Inc., Melville, N.Y., USA). Images were captured with a Cool SNAP fx camera (Photometrics, Tuscan, Ariz., USA) and MCID Elite 6.0 software (Life Sciences, Piscataway, N.J., USA).

\section{Double-Label ICC for $\mathrm{O} 4$ and $\mathrm{OI}$}

Double labeling with monoclonal antibodies $\mathrm{O} 4$ and $\mathrm{O} 1$ for detection of OLs [43] was performed using paraformaldehydefixed, free-floating sections. Paraformaldehyde-fixed tissue was cryoprotected in PBS containing 30\% sucrose and frozen. Frozen tissue was cut on a cryostat at $40 \mu \mathrm{m}$ and collected in cold PBS. Tissue was incubated with either $\mathrm{O} 4$ or $\mathrm{O} 1$ antibody [43] in PBS containing $5 \%$ goat serum overnight at $4^{\circ} \mathrm{C}$, followed by a 1 -hour incubation in Alexa-Fluor goat anti-mouse 594 IgM antibody (Molecular Probes). Tissue was then incubated with anti-12/15-LOX in PBS containing $5 \%$ goat serum $/ 0.1 \%$ Triton X-100 overnight at $4{ }^{\circ} \mathrm{C}$. Sections were mounted onto slides and immunofluorescence was visualized as above.

\section{Quantitation of $\mathrm{O} 4$ and $\mathrm{O} 1$ Double-Label ICC}

Sections double-labeled with 12/15-LOX and O4 or O1 OL markers were examined to determine the percentage of $\mathrm{O} 4$ and $\mathrm{O} 1$ OLs that expressed 12/15-LOX. Sections were stained as described above. After a survey of the entire section, 5-10 fields (magnification $\times 40$ ) within the most intensely stained area of tissue within the periventricular white matter were examined. The percentage of O4/O1-positive cells that expressed 12/15-LOX was determined by counting all O4/O1-positive cells that expressed 12/15-LOX and dividing that by all cells that expressed O4/O1.

\section{TUNEL Combined with 12/15-LOX ICC}

Frozen tissue was sectioned in the cryostat at $30 \mu \mathrm{m}$. Tissue was fixed for $10 \mathrm{~min}$ in 4\% paraformaldehyde in PBS followed by three 5-min washes in PBS. TUNEL was performed using the Apop Tag Plus Fluorescein In Situ Apoptosis Detection Kit (Millipore) according to the manufacturer's instruction. Following TUNEL, tissue was blocked in PBS containing 5\% goat serum and $0.05 \%$ Triton $\mathrm{X}-100$ for $1 \mathrm{~h}$ at room temperature, and incubated overnight at $4^{\circ} \mathrm{C}$ in blocking solution containing the antibody to $12 / 15$-LOX 
at 1:200. After a series of washes, the tissue was incubated in blocking solution containing Alexa-Fluor goat anti-rabbit 590 at a concentration of 1:1,000 (Molecular Probes).

\section{Statistics}

Age-adjusted differences in PVL relative to controls were assessed using analysis of covariance (ANCOVA) adjusting for postconceptional (PC), postnatal (PN), and gestational age.

\section{Results}

\section{Clinical Database}

For all immunochemical analyses in frozen or paraformaldehyde-fixed, paraffin-embedded and non-paraffinembedded tissue, we analyzed 12/15-LOX expression in the cerebral white matter of 28 cases of PVL and 15 control cases without PVL (table 1). The PVL cases ranged in age from 29 to $43 \mathrm{PC}$ weeks (median of 35.5 PC weeks) and 0-8 PN weeks (median of $1.5 \mathrm{PN}$ weeks); the controls ranged from 20 to $43 \mathrm{PC}$ weeks (median of $33.5 \mathrm{PC}$ weeks) and $0-2.5 \mathrm{PN}$ weeks (median of $1 \mathrm{PN}$ week). The ages and primary causes of death of each case used are listed in table 1. Also listed is the presence of germinal matrix hemorrhage and infection. The postmortem interval ranged from 6 to $25 \mathrm{~h}$ for the PVL cases with outliers at 44 and $89 \mathrm{~h}$, and $4-25 \mathrm{~h}$ for the control cases.

\section{Neuropathology of PVL}

Each of our PVL cases were designated as such based on the presence of a focal necrotic lesion within the white matter. The stage and degree of severity of the focal necrosis varied, however, reflecting the typical spectrum of this pathology in our autopsy service. 54\% (15 out of 28) of the PVL cases had recognizable focal periventricular necrosis at the time of brain cutting (table 1). These were described grossly as either cystic lesions or chalky-white foci of necrosis, the classic so-called 'white spots' of PVL. In the remaining $46 \%$ of the total PVL cases in this series (13 out of 28 ), the necrotic foci were detected only microscopically and varied in size up to approximately $2 \mathrm{~mm}$ (table 1).

\section{Normative Expression of 12/15-LOX}

In the time frame examined, the second half of gestation, there was little 12/15-LOX expression in the white matter of controls as seen in paraformaldehyde-fixed, paraffin-embedded cases $(n=10)$. Scattered positive cells were detectable in 4 out of 10 control cases and were given density scores of either 0.5 or 1 as indicated: case 9 at 34 PC weeks (density score of 0.5 ); case 12 at 38 PC weeks (density score of 1.0); case 14 at 40 PC weeks (density score of 0.5 ), and case 15 at 43 PC weeks (density score of 1.0). There were 6 control cases from 20 to 34 PC weeks which showed no staining within the white matter (density score of 0 ) as scored in the DAB-stained sections. In the cases with 12/15-LOX-positive cells, we examined 12/15-LOX expression in microglia using an antibody to tomato lectin, a general microglial marker that labels resting and activated microglia. Of the scattered $12 / 15$-LOX-expressing cells, approximately $80 \%$ showed colocalization with tomato lectin (fig. 1a). In these same cases, we looked for colocalization with CD68, an antibody which marks phagocytic macrophages and reactive microglia, and found little expression of CD68 (data not shown). In control cases, we also examined the expression of 12/15-LOX in pre-OLs of the $\mathrm{O} 4$ and $\mathrm{O} 1$ stage. We did identify scattered O4- and O1-positive OLs with 12/15LOX expression (fig. 1b). In the cerebral cortex, positive cell bodies of neurons were detected in 3 out of $10 \mathrm{DAB}-$ stained controls (30\%) at 34 (case 10), 40 (case 14) and 43 (case 15) gestational weeks (fig. 1c and 1d). In these cases, there were neuronal cells of granular and pyramidal morphology expressing 12/15-LOX in all layers of the cortex. The presence of these 12/15-LOX-positive cells was seemingly random throughout the cortex examined.

\section{Cell-Specific Expression of 12/15-LOX in the Focal and} Diffuse Components of PVL

In the paraffin-embedded PVL cases, we identified 12/15-LOX expression in large round cells morphologically consistent with macrophages and/or ameboid microglia within and around the focally necrotic lesions. These cells were confirmed as macrophages/ameboid microglia by colocalization with CD68 (fig. 2).

In the diffusely gliotic component of PVL surrounding and distant from the focal necrosis, we found 12/15-LOXpositive cells in the white matter. These cells had the morphological appearance of microglia characterized by bipolar thick processes [44] (fig. 3a), or of OLs characterized by a central, dark, round, and small nucleus and often with a 12/15-LOX-stained process extending towards an axon (fig. 3a). We also observed scattered cells of unknown type with 12/15-LOX-positive nuclei in the white matter of PVL cases (fig. 3b). The 12/15-LOX expression appeared qualitatively increased in the white matter in PVL (fig. 3a, b) compared to controls (fig. 3c). To confirm this visual difference, we used a semiquantitative scoring system of $0-3$ and found a significant increase $(\mathrm{p}=0.014)$ in the density of $12 / 15$-LOX-expressing cells in PVL (score of $1.17 \pm 0.15$ cells/HPF) compared to 
Table 1. Clinical summary of cases

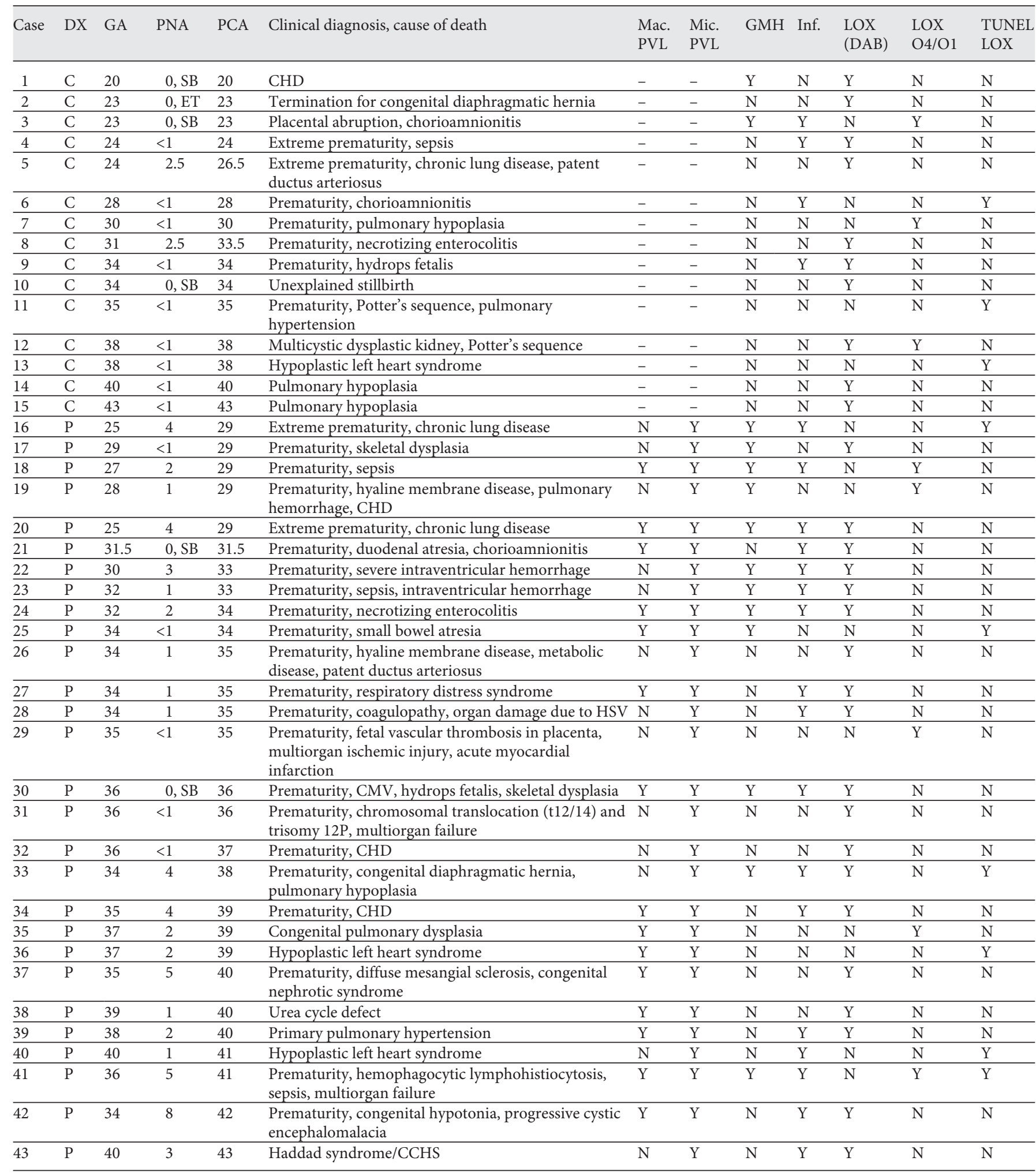

DX = Diagnosis; $\mathrm{C}=$ control; $\mathrm{P}=\mathrm{PVL} ; \mathrm{GA}=$ gestational age (weeks); PNA = postnatal age (weeks); PCA = postconceptional age (weeks); Mac. PVL = macroscopic PVL; Mic. PVL = microscopic PVL; GMH = germinal matrix hemorrhage; Inf. = infection; $\mathrm{SB}=$ stillbirth; $\mathrm{ET}=$ elective termination; $\mathrm{CHD}=$ congenital heart disease; $\mathrm{HSV}=$ herpes simplex virus; $\mathrm{CMV}=$ cytomegalovirus; $\mathrm{CCHS}=$ congenital central hypoventilation syndrome; $\mathrm{Y}=$ yes; $\mathrm{N}=$ no. 
Fig. 1. 12/15-LOX expression in controls. a 12/15-LOX expression shows colocalization with the microglial marker tomato lectin in the white matter of a control case at 34 PC weeks. Magnification $\times 40$. b A rare 12/15-LOX-expressing O4 cell is detected in the white matter of a control case at 37 PC weeks. Magnification $\times 40$. c, d Scattered neuronal cells throughout all layers express 12/15-LOX in a control case at 40 PC weeks. Neurons are shown at low magnification (c, scale bar $=200 \mu \mathrm{m})$ and at high magnification $(\mathbf{d}$, scale bar $=100 \mu \mathrm{m})$. c 12/15-LOX expression is shown in pyramidal neurons (arrow) and granular neurons (arrowhead).

Fig. 2. $12 / 15$-LOX expression in macrophages of the focal necrotic lesion of PVL. a Shown is a representative hematoxylineosin-stained section of a posterior frontal section of PVL with a macrocyst (arrow) and microcystic lesions (asterisks) in the periventricular white matter. b 12/15-LOX is expressed in the macrophages and/or ameboid microglia of the microcystic lesion as seen by DAB staining. Magnification $\times 20$ (scale bar $=200 \mu \mathrm{m})$. c Macrophages/ameboid microglia within the focal lesion show colocalization with macrophage/microglia marker CD68 and 12/15LOX. Magnification $\times 40$.
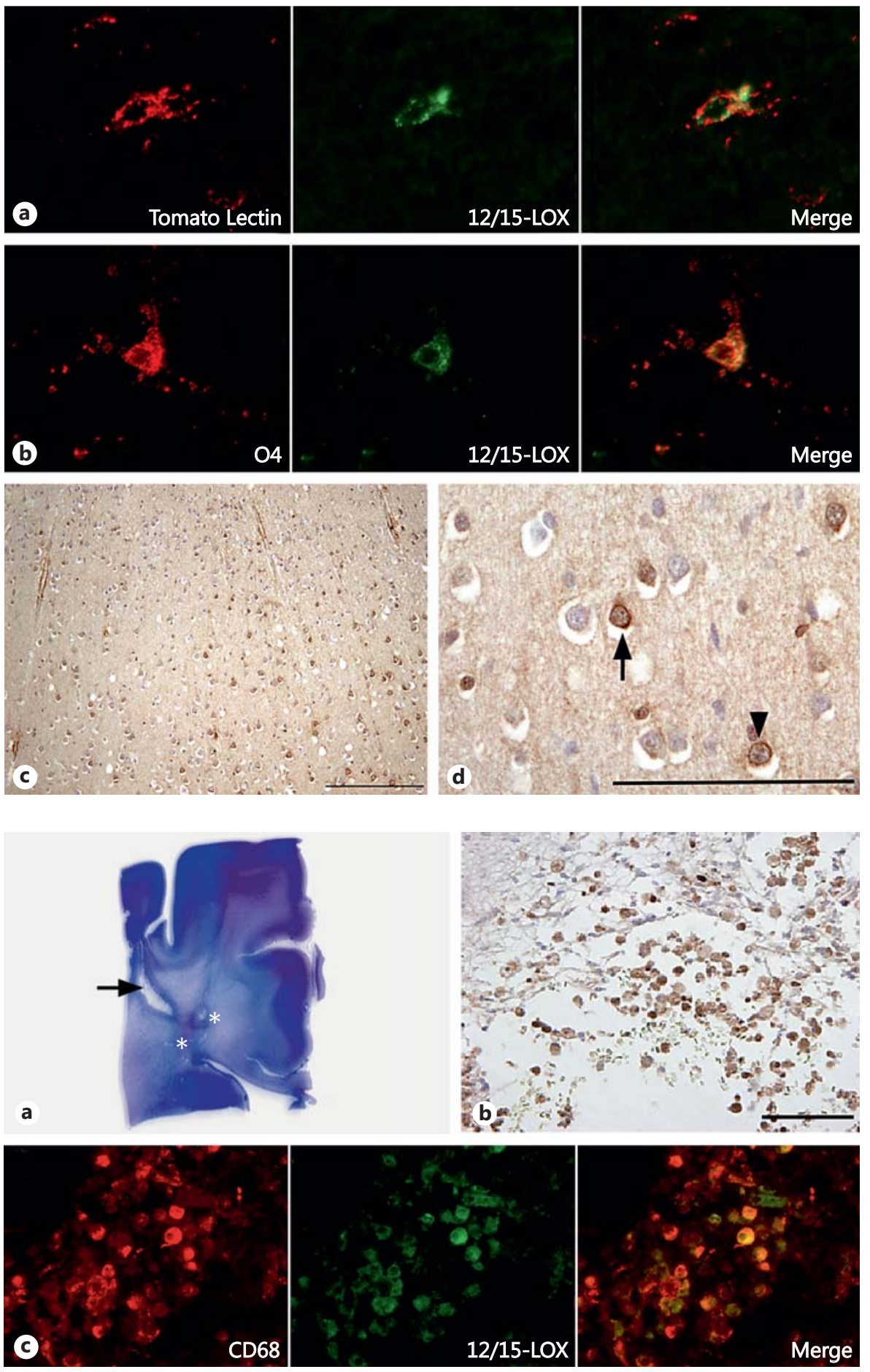

controls (score of $0.48 \pm 0.21$ cells/HPF) during the second half of gestation (fig. 4). Examination of the number of cases scored 0-3 revealed a larger number of control cases with scores of 0 and $0.5(n=8$ out of $10 ; 80 \%)$ relative to the PVL cases which showed an increased number of cases with scores of 1 and 2 ( $n=15$ out of $19 ; 79 \%$ ). ANCOVA showed no effect of postmortem interval ( $\mathrm{p}=$ 0.15 ) in a model that controlled for diagnosis. Of note, there was no significant expression of 12/15-LOX in the cerebral cortex of PVL cases (data not shown). 

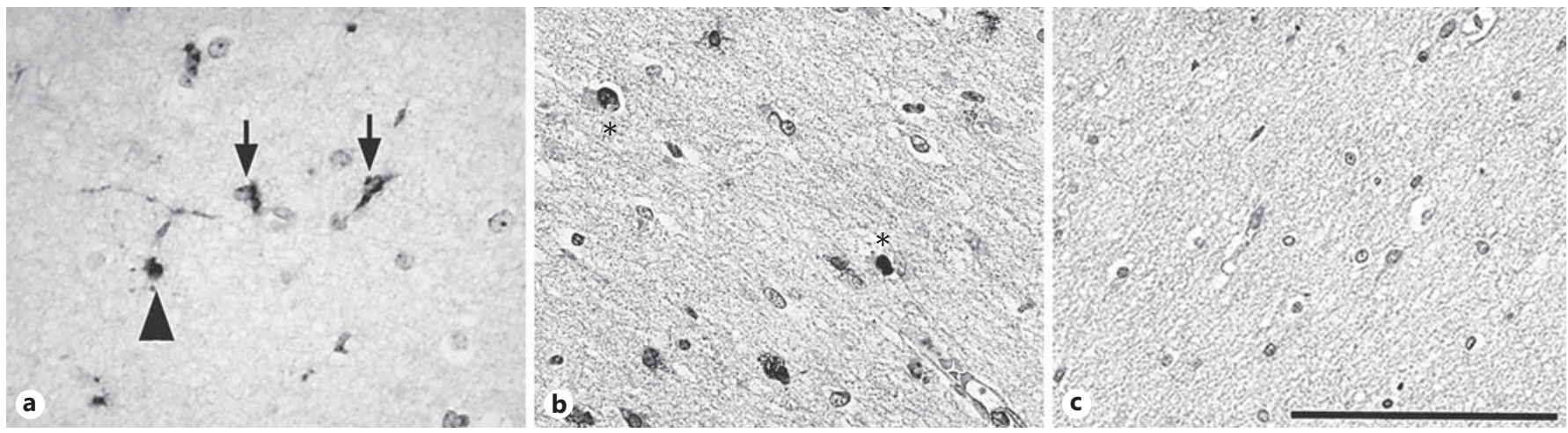

Fig. 3. 12/15-LOX expression in the diffusely gliotic lesion of PVL. All images are shown at a magnification of $\times 40$, scale bar $=100 \mu \mathrm{m}$. a 12/15-LOX is expressed in glial cells of the diffusely gliotic lesion in a PVL case at 40 PC weeks. Arrows indicate cells with the morphological appearance of microglia. The arrowhead indicates a cell with the appearance of an OL. b 12/15-LOX expression is detected in scattered nuclei (asterisks) of cells in the gliotic white matter of a PVL case at 39 PC weeks. c There is no detectable expression of $12 / 15$-LOX in the white matter of a control case at 40 PC weeks.
In the diffuse component of PVL, we used double-label ICC to examine the cell-specific expression of 12/15LOX. Using CD68, in the PVL cases we found that while a population of CD68-positive reactive microglia colocalized with $12 / 15$-LOX (fig. 5a), there was a population of reactive microglia that did not express $12 / 15$ - LOX (fig. 5b). In a quantitative analysis of 5 PVL cases, we found that an average of approximately $75 \%$ (range of 43-96\%) of CD68-positive reactive microglia colocalized with 12/15-LOX. The percentages of CD68 cells that were positive for 12/15-LOX are listed for each case quantitatively examined (table 2). Using GFAP as a marker of reactive astrocytes, we found no colocalization with 12/15LOX in GFAP-positive cells throughout the white matter of PVL (fig. 5c).

We examined 12/15-LOX expression in O4-positive pre-OLs and O1-positive immature OLs in 5 PVL cases ranging from 29 to 41 postconceptional weeks. We found colocalization of 12/15-LOX with both $\mathrm{O} 4$ and O1 OLs (fig. 6). In the population of O4-positive pre-OLs, approximately $10 \%$ (range of $6-15 \%$ ) of OLs expressed $12 / 15$ LOX (table 3). In our analyses of O1 cells, we found the number of $\mathrm{O} 1$ cells (average of $1-3$ cells/HPF) to be low compared to $\mathrm{O} 4$ cells (average of $4-8$ cells/HPF). Within this very small population of $\mathrm{O} 1$ cells, however, we did see occasional cells expressing 12/15-LOX (table 3). In PVL cases, we also examined the expression of $12 / 15-\mathrm{LOX}$ in mature OLs. 12/15-LOX expression was seen in cells with the morphological appearance of mature OLs characterized by a central, dark, round, and small nucleus and perinuclear halo, the so-called fried egg appearance of mature
Table 2. 12/15-LOX double-label data for CD68-positive cells in PVL

\begin{tabular}{lllll}
\hline Case & $\begin{array}{l}\text { PC age } \\
\text { weeks }\end{array}$ & $\begin{array}{l}\text { CD68 cells } \\
\text { positive for } \\
12 / 15-\text { LOX }\end{array}$ & $\begin{array}{l}\text { Total } \\
\text { CD68 cells }\end{array}$ & $\begin{array}{l}\text { CD68 cells } \\
\text { positive for } \\
12 / 15 \text { LOX } \\
\%\end{array}$ \\
\hline 17 & 29 & 2.8 & 3.0 & 93.3 \\
23 & 33 & 2.2 & 4.2 & 52.4 \\
28 & 35 & 4.8 & 5.0 & 96.0 \\
33 & 38 & 2.0 & 4.7 & 42.6 \\
34 & 39 & 5.6 & 6.3 & 88.9 \\
39 & 40 & 4.5 & 5.9 & 76.3 \\
\hline
\end{tabular}

Case numbers are from table 1 . Cell numbers are an average of 5- 10 representative HPFs $(\times 40)$.

OLs [45] (fig. 7). Expression was also found in these cells with 12/15-LOX-positive processes extending towards axons (fig. 7). We found colocalization of 12/15-LOX with the mature OL marker APC (fig. 7). Because APC also labels reactive astrocytes (which are negative for 12/15LOX), we were unable to get an estimate of the number of mature OLs that express 12/15-LOX.

Lastly we examined the relationship between 12/15LOX expression and cells undergoing cell death using TUNEL methodology combined with $12 / 15$-LOX ICC. In the PVL cases examined $(n=6)$, we found scattered TUNEL-positive cells that expressed 12/15-LOX throughout the damaged white matter (fig. 8a). We also found cells 
Table 3. 12/15-LOX double-label data for O4- and O1-positive cells in PVL

\begin{tabular}{lllll}
\hline Case & $\begin{array}{l}\text { PC age } \\
\text { weeks }\end{array}$ & $\begin{array}{l}\text { O4 cells positive } \\
\text { for 12/15-LOX }\end{array}$ & $\begin{array}{l}\text { Total } \\
\text { O4 cells }\end{array}$ & $\begin{array}{l}\text { O4 cells positive } \\
\text { for 12/15-LOX } \\
\%\end{array}$ \\
\hline 18 & 29 & 0.6 & 3.9 & 15.4 \\
19 & 29 & 0.4 & 6.4 & 6.2 \\
29 & 35 & 0.5 & 5.5 & 9.1 \\
35 & 39 & 0.8 & 7.5 & 10.7 \\
41 & 41 & 0.6 & 4.8 & 12.5 \\
\hline Case & PC age & O1 cells positive & Total & O1 cells positive \\
& weeks & for 12/15-LOX & O1 cells & for $12 / 15-\mathrm{LOX}$ \\
& & & & $\%$ \\
\hline 18 & 29 & 1.0 & 1.6 & 62.5 \\
19 & 29 & 2.6 & 3.2 & 81.2 \\
29 & 35 & 0.6 & 1.8 & 33.3 \\
35 & 39 & 1.0 & 2.6 & 38.5 \\
41 & 41 & 0.3 & 1.0 & 30.0 \\
\hline
\end{tabular}

Case numbers are from table 1. Cell numbers are an average of 5-10 representative HPFs $(\times 40)$.

positive only for 12/15-LOX in the vicinity of cells that were positive only for TUNEL (fig. 8b). While this latter pattern was seen in all PVL cases examined, each of those PVL cases also had clusters of cells positive only for 12/15LOX and clusters of cells positive only for TUNEL (data not shown). Also identified in the PVL cases were scattered, albeit rare, cells with nuclear colocalization of TUNEL and 12/15-LOX (fig. 8c). In the control cases examined $(n=3)$, we did identify scattered, rare TUNEL-positive cells in the white matter. Very little 12/15-LOX expression was seen in the controls.

\section{Discussion}

In this study, we present novel evidence for a potential role of 12/15-LOX in the pathogenesis of PVL directly in the developing human brain, with important implications for translational research. In this study, we demonstrate expression of 12/15-LOX in the damaged white matter of cases with PVL during the second half of gestation. Constitutive expression of $12 / 15$-LOX is low as seen in adult human cortical neurons $[38,39]$ and in mature neurons $[46,47]$, OLs [48] and astrocytes of animal models [47, 48]. This low constitutive level, however, increases significantly in rodent models of transient focal ischemia [42,

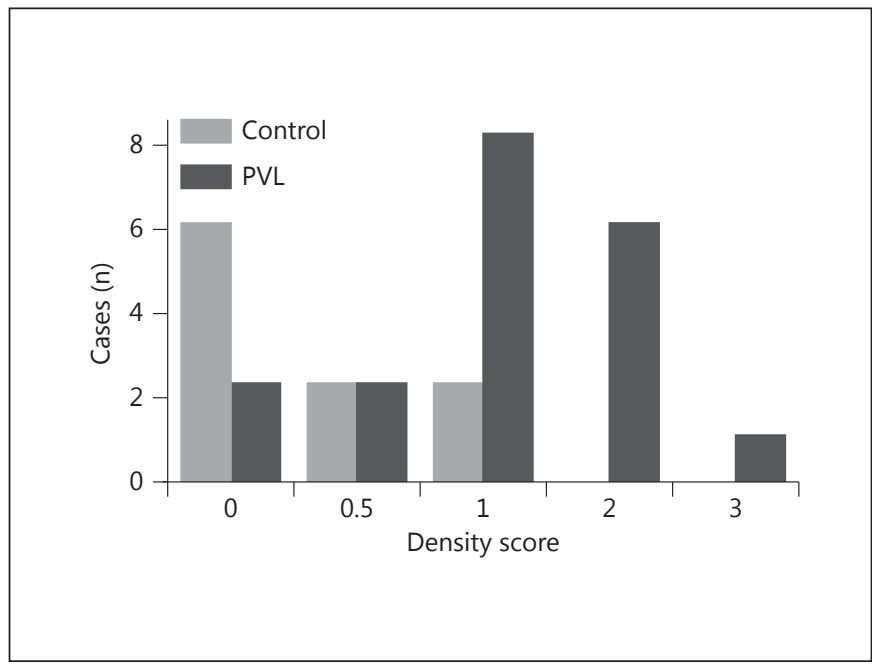

Fig. 4. 12/15-LOX cell density in PVL and controls. Semiquantitative analysis using a standardization density score for 12/15-LOXexpressing cells indicates an increase in 12/15-LOX density in PVL cases compared to controls $(\mathrm{p}=0.014)$. The graph shown indicates the number of cases and controls given a specific density score of $0-3$.

$46,49,50]$ and in human Alzheimer's disease [38] and stroke [39], thus implicating 12/15-LOX in the pathology of these conditions. Lipoxygenases are involved in the metabolism of AA to form oxidized derivatives of AA and leukotrienes. The best-characterized role for LOX activity in the brain is the generation of metabolites in inflammatory responses. Below we discuss the potential significance of our finding of 12/15-LOX expression in inflammatory cells within the damaged white matter in PVL, specifically macrophages and activated microglia. We also discuss the implications of our finding of expression of 12/15-LOX in OLs of different stages in PVL in terms of OL loss or damage and potential therapeutic targets for myelin deficits in long-term survivors of PVL.

\section{2/15-LOX in Development}

In our control tissue, we saw 12/15-LOX expression in scattered resting (tomato lectin-positive/CD68-negative) microglia, scattered and rare O4- and O1-positive OLs, and cortical neurons beginning at 34 gestational weeks. The lack of expression prior to 34 gestational weeks suggests a temporal development of constitutive 12/15-LOX expression within these cells with onset in the third trimester. In studies of mature neurons, evidence suggests a role of $12 / 15$-LOX in synaptic plasticity and neurotransmission [51-53]. Given this evidence, the expression of 

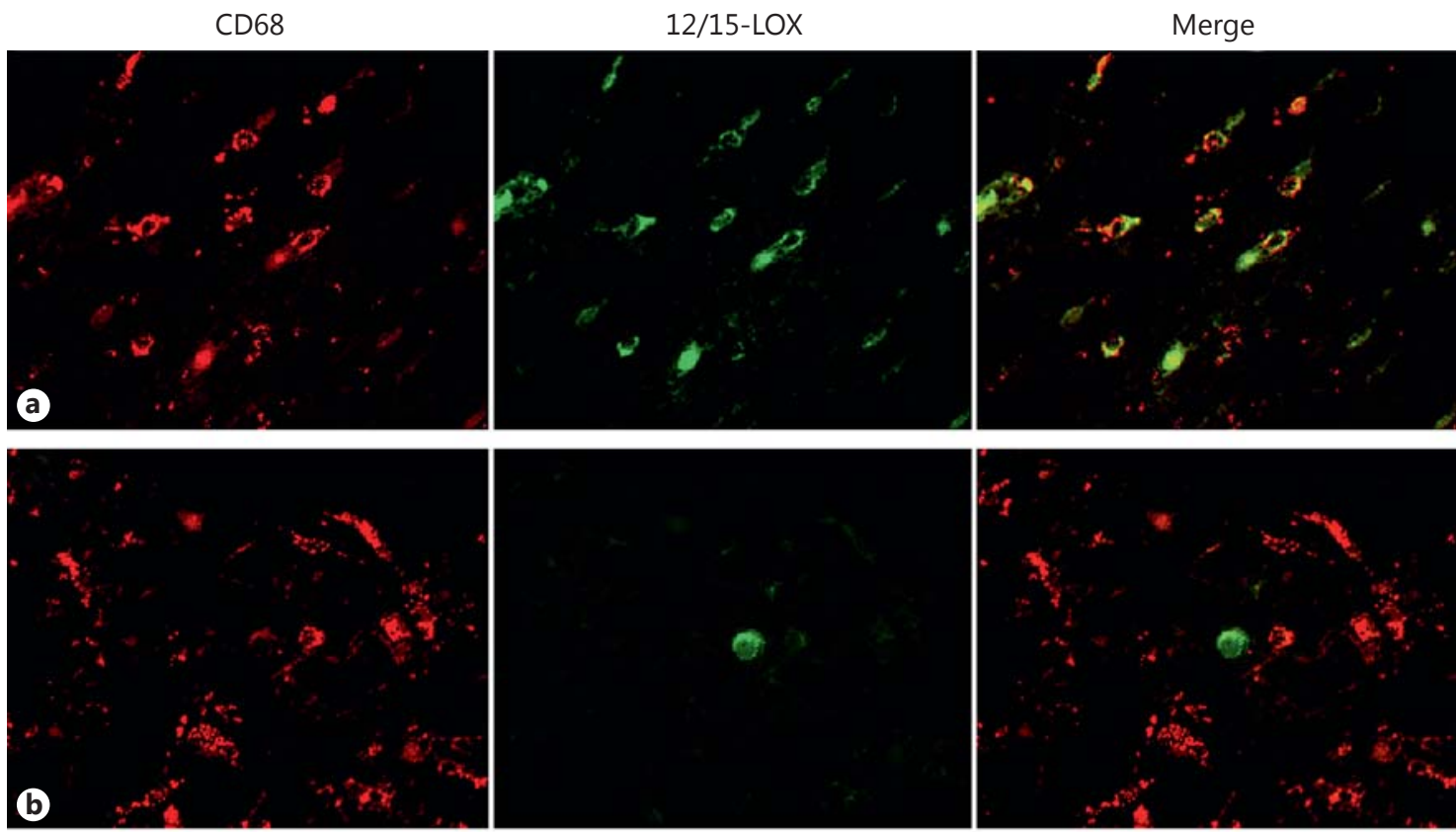

\section{GFAP}

12/15-LOX
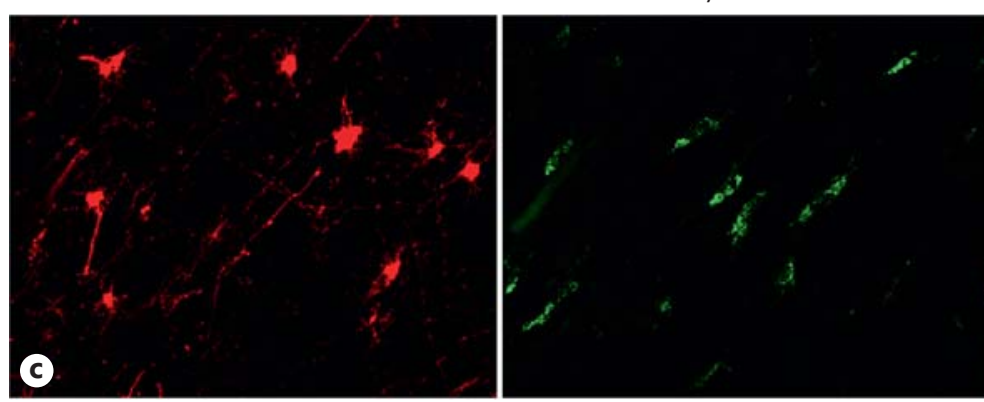

Merge

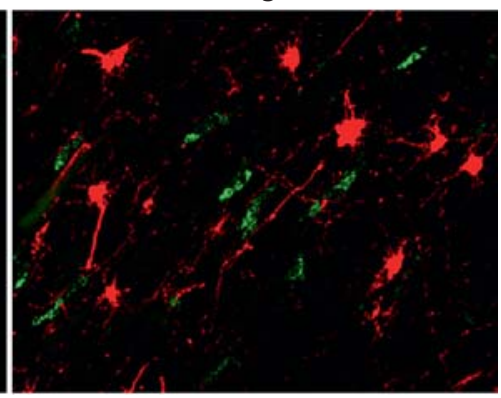

Fig. 5. 12/15-LOX expression in reactive microglia and reactive astrocytes of the diffuse component. All images are shown at a magnification of $\times 40$. a $12 / 15$-LOX is expressed in a population of CD68-positive activated microglia in the diffuse component of PVL. $\mathbf{b}$ There is a population of CD68-positive activated microglia in the diffuse component of PVL that does not show colocalization

with 12/15-LOX. Based on morphology, the 12/15-LOX-positive/ CD68-negative cell is likely to be a mature OL. Both $\mathbf{a}$ and $\mathbf{b}$ are from a PVL case at 40 PC weeks. c There is no colocalization of $12 / 15$-LOX with the reactive astrocyte marker GFAP in a PVL case at $38 \mathrm{PC}$ weeks.

$12 / 15$-LOX in a population of neurons in our older $(>34$ gestational weeks) controls may represent the onset of a mature constitutive, yet low expression of the enzyme. The expression of 12/15-LOX in the small subset of microglia may represent a developmental expression consistent with the developmental changes occurring in the microglial population during this period of time [44]. The function of 12/15-LOX expression in developing OLs is currently unknown. Alternatively, the scattered expression in each of these cell types may represent mild pathological changes in our controls associated with terminal complications, given that the controls are comprised of infants with systemic illnesses likewise complicated by hypoxia but without PVL, as in virtually all autopsy studies of the neuropathology of prematurity [54].

\section{2/15-LOX in OLs in PVL}

In this study, we observed 12/15-LOX expression in PVL in OLs of all stages of cell lineage. In rat cultures of O4-positive pre-OLs, 12/15-LOX expression plays a role in OL cell death under conditions of oxidative stress [35, 37, 55]. Glutathione depletion results in an increase in 12/15-LOX activity, ROS accumulation, and OL cell death [35]. Inhibition of the 12/15-LOX activity, on the 
Fig. 6. 12/15-LOX expression in OL of the premyelinating $(\mathrm{O} 4)$ and immature $(\mathrm{O} 1)$ stages. a There is colocalization of $12 / 15$ LOX with the $\mathrm{O} 4$ marker of premyelinating OLs in a PVL case at 30 PC weeks. b There is colocalization of $12 / 15$-LOX with the $\mathrm{O} 1$ marker of immature OLs in a PVL case at 30 PC weeks.
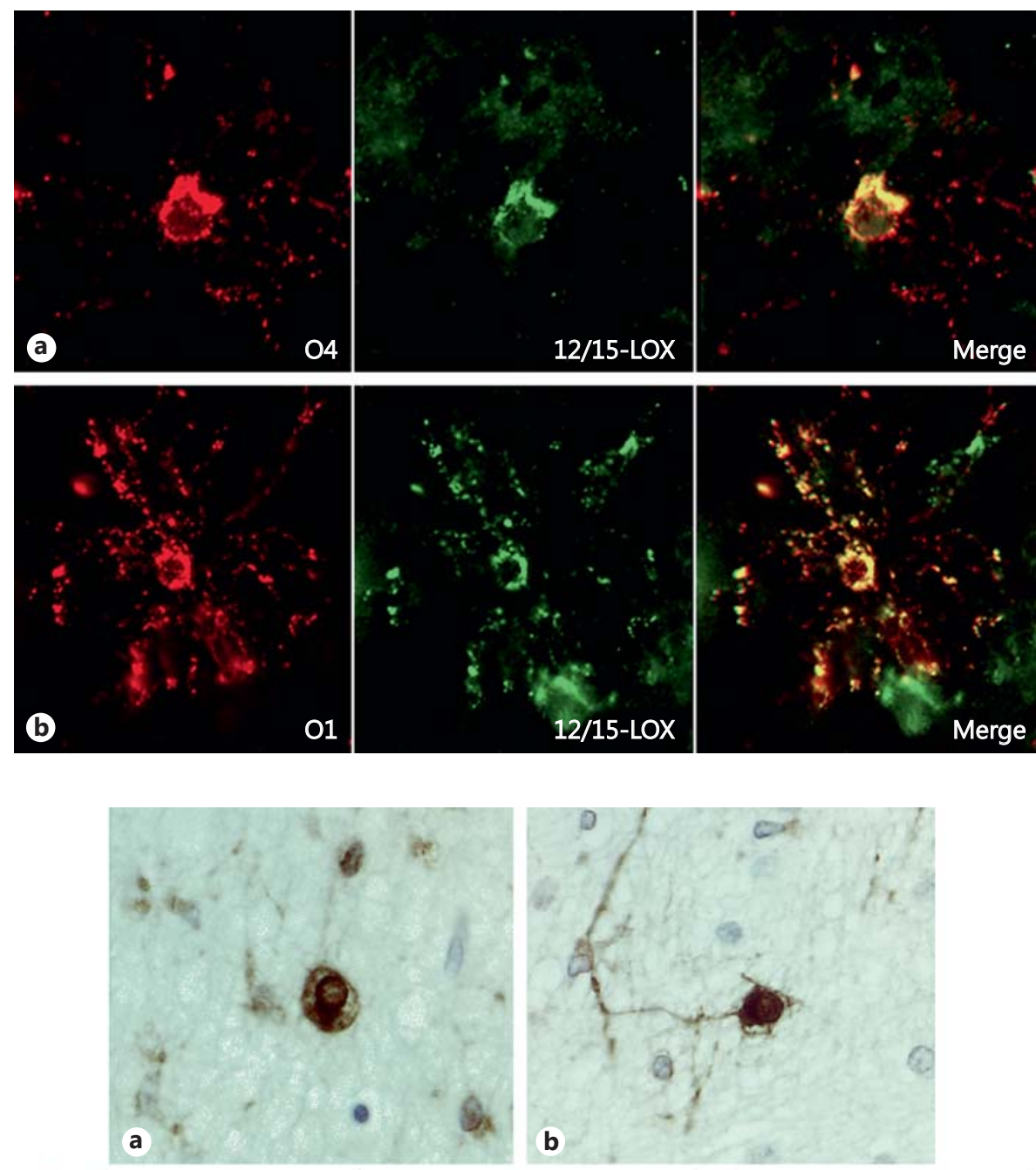

Fig. 7. 12/15-LOX expression in mature OLs. a, b 12/15-LOX is expressed in cells with the morphological appearance of mature OLs as determined by DAB staining in a PVL case at $38 \mathrm{PC}$ weeks. c $12 / 15-\mathrm{LOX}$ is colocalized with the mature OL marker APC in a PVL case at 33 PC weeks. Magnification $\times 40$.

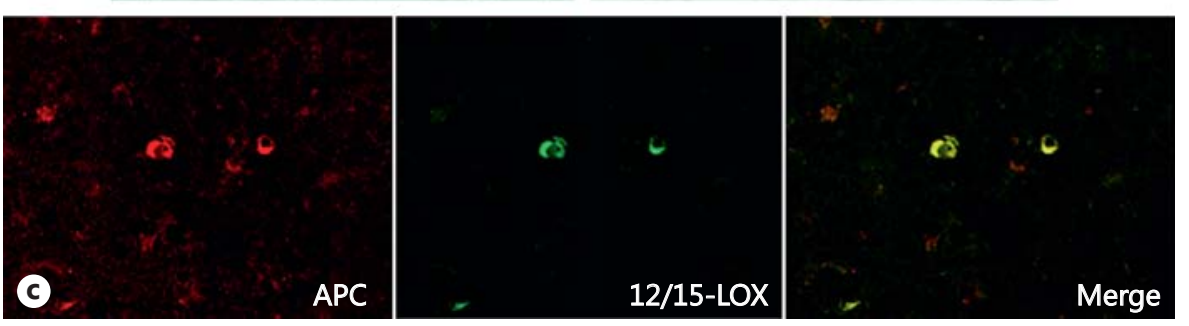

other hand, effectively blocks both the production of ROS and pre-OL cell death [35]. Our finding of 12/15-LOX expression at all stages of OLs suggests that each stage is potentially vulnerable to $12 / 15$-LOX-mediated cell damage. An increase in resistance of mature OLs in cultures to oxidative stress-induced cell death [56-60], however, suggests that mature OLs in PVL are likely to be more resistant despite their expression of $12 / 15$-LOX. This is likely due to increased cellular defenses at more developed stages of OL lineage $[61,62]$.

12/15-Lipoxygenase in PVL
In PVL, we and others have shown an acute loss of pre-OLs in the diffuse component [9-11] with further evidence of apoptotic pre-OL cell death as determined by TUNEL staining $[9,10]$. In addition, we have shown evidence of oxidative injury directly in OLs of the diffuse component of PVL, as determined by the presence of the lipid peroxidation marker 4-hydroxynonenal [9]. Given our finding of 12/15-LOX expression in OLs, we hypothesize two different models for 12/15-LOX-mediated OL cell death in PVL. The first model involves the 
direct release of ROS through the activation of 12/15LOX and subsequent metabolism of AA. These ROS can originate from 2 sources: (1) exogenous expression of $12 / 15$-LOX in microglia within the diffuse component of PVL (see below), and/or (2) endogenous expression of 12/15-LOX within OLs themselves. Either source of ROS can oxidatively damage the OLs and result in OL cell death, particularly in pre-OLs which are known to be more vulnerable to oxidative damage [56-60]. In the damaged white matter of PVL, we have shown areas with 12/15-LOX-positive cells in close proximity to TUNELpositive cells. We have also identified TUNEL-positive cells that express 12/15-LOX. While not direct evidence, these data support our hypothesis of the involvement of 12/15-LOX in cell death in PVL through exogenous (via microglial 12/15-LOX expression) or endogenous AA metabolism and release of ROS. The second model of 12/15-LOX-mediated OL cell death involves a potential role for direct mitochondrial damage in OLs and the subsequent release of mitochondrial apoptosis-inducing factor, which is implicated in caspase-independent forms of cell death $[21,39,42,63,64]$. This model of direct contributions of 12/15-LOX to cell death is supported by the finding of cells staining for both TUNEL and 12/15-LOX (fig. 8). Of note, in the gliotic white matter, we detected scattered cells with 12/15-LOX-positive nuclei, a finding consistent with those in ischemic brain injury [42]. We also detected scattered cells with TUNEL-positive cells with nuclear localization of 12/15LOX, suggesting that at least some of the cells with nuclear colocalization are in the process of dying. Further analyses need to be done in PVL to examine this population of cells in regard to cell-specific expression and possible apoptosis-inducing factor colocalization. Of note, while acute pre-OL cell loss has been shown in PVL [9$11]$, evidence in human $[65,66]$ and in perinatal rodent models [67] suggests that this loss is compensated for, likely by proliferation of surviving pre-OLs [67].

\section{2/15-LOX in Inflammatory Cells of PVL}

In this study, we show that $12 / 15$-LOX is expressed in macrophages/activated microglia of the focal necrosis and in a subpopulation of reactive microglia of the diffuse component of PVL. It is unclear as to what accounts for the differences in the 12/15-LOX-expressing and nonexpressing microglia. One possibility is that the different expression patterns of 12/15-LOX reflect a distinct timing of expression in the process of microglial activation. Alternatively, the two distinct populations are of different inflammatory reaction-related phenotypes, specifically
M1 microglia classically activated by microbial compounds or proinflammatory cytokines to produce more proinflammatory cytokines, or M2 alternatively activated microglia with an anti-inflammatory phenotype promoting tissue repair [68-70]. A characterization of these different phenotypes relative to $12 / 15$-LOX expression is currently under way.

Whether M1 or M2 microglia, the expression of 12/15LOX by microglia may play a critical role in their downstream inflammatory responses which are activated initially by $\mathrm{H}-\mathrm{I}$ and/or systemic infection $[2,17-20]$. Activation of 12/15-LOX within the microglia may serve as a potent source of ROS in PVL, and widespread release of ROS by activated microglia within the diffuse component of PVL may play an important role in OL damage. We and others have shown evidence of oxidative stress in the white matter of PVL $[9,10]$; the current findings suggest that $12 / 15$-LOX upregulation in microglia constitutes at least one important source of this stress. Alternatively, we cannot rule out the possibility that a population of 12/15-LOX-expressing microglia may have an anti-inflammatory role given that $12 / 15$-LOX can, in conjunction with other enzymes, generate inflammation-limiting lipoxins, resolvins and protectins [30-32]. Of note, 12/15LOX, in response to interleukin 4 , induces the expression of peroxisome proliferator-activated receptor $\gamma$ and the subsequent transcription of macrophage-expressed CD36, an antigen associated with the M2 anti-inflammatory phenotype [71].

In PVL, we found no expression of $12 / 15$-LOX in reactive astrocytes in the diffuse component of PVL. This is consistent with animal models of stroke [50], but differs from the finding of 12/15-LOX expression of reactive astrocytes in Alzheimer's disease [38]. Interestingly, 12LOX mRNA is significantly increased in cultured rat neonatal astrocytes following hypoxia and reoxygenation [27]. In our study, we did not examine mRNA levels of $12 / 15$-LOX and, therefore, cannot rule out the possibility of increased transcription of 12/15-LOX in astrocytes of PVL. However, the lack of 12/15-LOX protein expression in astrocytes suggests that $12 / 15$-LOX activity does not play a role in the astrocytic inflammatory response in PVL [50].

\section{Lack of 12/15-LOX Expression in the Cerebral Cortex in $P V L$}

In our studies, we surprisingly did not see 12/15-LOX expression in neurons of the cerebral cortex in PVL. This differs from the finding of $12 / 15$-LOX expression in entorhinal cortical neurons in Alzheimer's disease [38] and 


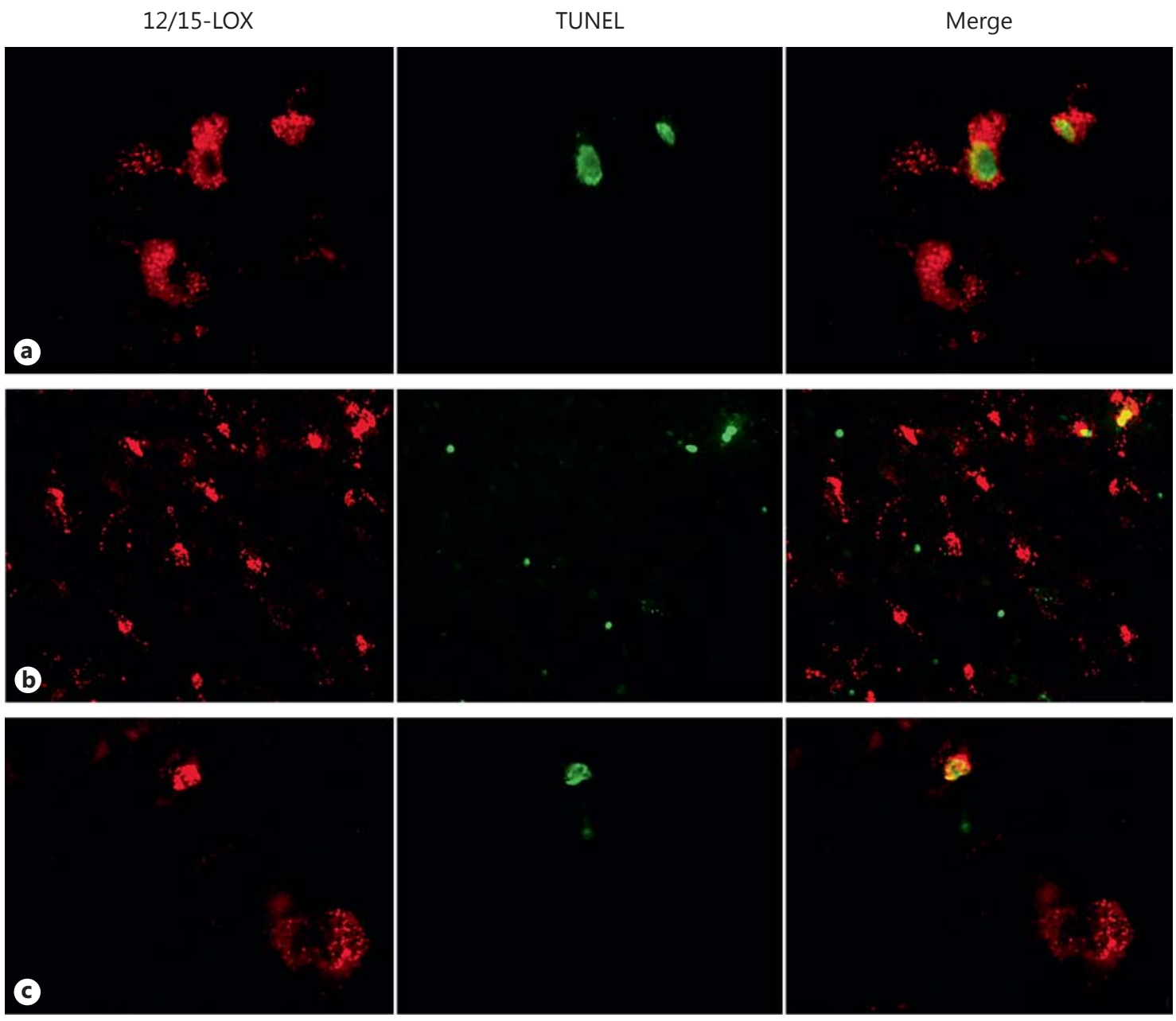

Fig. 8. Relationship between TUNEL-positive cells and 12/15-LOX expression. a In a case at 39 PC weeks, 2 TUNEL-positive cells show colocalization with cytoplasmic 12/15-LOX expression. Also shown is a 12/15-LOX-positive cell negative for TUNEL. Magnification $\times 40$. $\mathbf{b}$ In a case at 41 PC weeks, a low-power $(\times 20)$ magnification shows cells positive for TUNEL only proximal to cells pos-

in mouse models of transient focal ischemia [42]. It also differs from findings in neuronal cultures showing an involvement in 12/15-LOX activity in models of injury induced by glutathione depletion $[22,42,72]$ and peroxynitrite exposure [73]. In PVL, involvement of the cerebral cortex overlying injured white matter is now evident with volumetric MRI studies showing a reduction in volume [2,74-79]. There is also pathological data in noncystic PVL showing evidence of neuronal loss and gliosis in the cerebral cortex [6] and a decrease in layer 5 pyramidal neurons in PVL compared to controls [7]. In each of these findings, it is uncertain whether the neuro- itive for 12/15-LOX. Also shown are 2 TUNEL-positive cells with colocalization of cytoplasmic 12/15-LOX expression. $\mathbf{c}$ In a case at 39 PC weeks, a TUNEL-positive cell is shown with nuclear colocalization of 12/15-LOX. Also shown is a 12/15-LOX-positive cell negative for TUNEL. Magnification $\times 40$. nal damage is primary or constitutes, rather, regressive changes secondary to the underlying white matter (axonal) damage. A third finding, however, of subtle but significant oxidative stress in cortical neurons overlying PVL [80] suggests that cortical neurons may, to some degree, be directly injured. In this case, our data suggests that this injury does not involve 12/15-LOX-mediated events. Alternatively, 12/15-LOX may be involved, but the timing of upregulation is such that $12 / 15$-LOX-mediated cell death occurs early in the development of the injury, prior to demise, thus precluding these cells from our analyses. 


\section{2/15-LOX in Systemic Inflammation/Infection}

In addition to H-I injury, 12/15-LOX is involved in the inflammatory response to certain pathogenic infections [81-83] and in response to stimulation by bacterial wall component lipopolysaccharide (LPS) [84, 85]. In our study, given the number of PVL cases with infection alone or in the setting of $\mathrm{H}-\mathrm{I}$, we cannot rule out the possibility that the increase in 12/15-LOX-positive cells in PVL was, in part, a response to infection.

\section{Conclusion}

In this study, we present evidence of a 12/15-LOX-mediated pathway in OL cell death and/or damage in PVL during the second half of gestation. 12/15-LOX expression in PVL likely represents a cell-specific inflammatory response to the pathogenic mechanisms involved in PVL, i.e. $\mathrm{H}-\mathrm{I}$ and systemic inflammation/infection. While this pathway has been identified as a potential target for therapy in animal and cell culture, confirmation of the 12/15-LOX pathway directly in the human neonate in this study offers potential new avenues for therapeutic targets that can help ameliorate or reduce damage and/or loss to the OLs.

\section{Acknowledgments}

We would like to acknowledge the following people for their guidance and input during the course of this study: Dr. Hannah C. Kinney for assistance with pathological concerns and questions regarding tissue and database; Dr. Rebecca D. Folkerth for continual support in obtaining tissue through the autopsy services at Boston Children's Hospital and Brigham and Women's Hospital; Dr. Joseph J. Volpe for guidance on issues relating to neonatal brain injury and clinical implications of our research, and Dr. Paul A. Rosenberg for initial guidance into the lipoxygenase field in PVL. We would like to especially acknowledge Dr. Hannah C. Kinney for her critical review and thoughtful input into the writing of this paper. This work was supported by the National Institutes of Health (PO1-NS38475; to R.L.H.), Cerebral Palsy International Research Foundation (to R.L.H.), and the National Institutes of Health (R01 NS049430; to K.v.L.).

\section{References}

1 Volpe JJ: Neurology of the Newborn, ed 5. Philadelphia, Saunders Co, 2008.

2 Volpe JJ: Brain injury in premature infants: a complex amalgam of destructive and developmental disturbances. Lancet Neurol 2009; 8:110-124.

-3 Volpe JJ, Kinney HC, Jensen FE, Rosenberg PA: The developing oligodendrocyte: key cellular target in brain injury in the premature infant. Int J Dev Neurosci 2011;29:423-440.

4 Kinney HC, Volpe JJ: Perinatal panencephalopathy in the premature infant: is it due to hypoxia-ischemia? In Haddad GG, Ping YS (ed): Brain Hypoxia and Ischemia. New York, Humana Press, 2009

$\checkmark 5$ Kinney HC, Volpe JJ: Modeling the encephalopathy of prematurity in animals: the important role of translational research. Neurol Res Int 2012;2012:295-389.

-6 Pierson CR, Folkerth RD, Billiards SS, Trachtenberg FL, Drinkwater ME, Volpe JJ, Kinney HC: Gray matter injury associated with periventricular leukomalacia in the premature infant. Acta Neuropathol 2007;114:619-631.

-7 Andiman SE, Haynes RL, Trachtenberg FL, Billiards SS, Folkerth RD, Volpe JJ, Kinney HC: The cerebral cortex overlying periventricular leukomalacia: analysis of pyramidal neurons. Brain Pathol 2010;20:803-814.

-8 Haynes RL, Billiards SS, Borenstein NS, Volpe JJ, Kinney HC: Diffuse axonal injury in periventricular leukomalacia as determined by apoptotic marker fractin. Pediatr Res 2008;63: 656-661.
9 Haynes RL, Folkerth RD, Keefe RJ, Sung I, Swzeda LI, Rosenberg PA, Volpe JJ, Kinney HC: Nitrosative and oxidative injury to premyelinating oligodendrocytes in periventricular leukomalacia. J Neuropathol Exp Neurol 2003;62:441-450.

10 Back SA, Luo NL, Mallinson RA, O'Malley JP, Wallen LD, Frei B, Morrow JD, Petito CK, Roberts CT Jr, Murdoch GH, Montine TJ: Selective vulnerability of preterm white matter to oxidative damage defined by $\mathrm{F} 2$-isoprostanes. Ann Neurol 2005;58:108-120.

11 Robinson S, Li Q, Dechant A, Cohen ML: Neonatal loss of gamma-aminobutyric acid pathway expression after human perinatal brain injury. J Neurosurg 2006;104:396-408.

12 Titomanlio L, Kavelaars A, Dalous J, Mani S, El Ghouzzi V, Heijnen C, Baud O, Gressens P: Stem cell therapy for neonatal brain injury: perspectives and challenges. Ann Neurol 2011;70:698-712.

13 Higgins RD, Raju T, Edwards AD, Azzopardi DV, Bose CL, Clark RH, Ferriero DM, Guillet R, Gunn AJ, Hagberg H, Hirtz D, Inder TE, Jacobs SE, Jenkins D, Juul S, Laptook AR, Lucey JF, Maze M, Palmer C, Papile L, Pfister $\mathrm{RH}$, Robertson NJ, Rutherford M, Shankaran S, Silverstein FS, Soll RF, Thoresen M, Walsh WF, Eunice Kennedy Shriver National Institute of Child H, Human Development Hypothermia Workshop S, and Moderators: Hypothermia and other treatment options for neonatal encephalopathy: an executive summary of the Eunice Kennedy Shriver NICHD workshop. J Pediatr 2011;159:851-858.
14 Passemard S, Sokolowska P, Schwendimann L, Gressens P: VIP-induced neuroprotection of the developing brain. Curr Pharm Des 2011;17:1036-1039.

15 Xiong T, Qu Y, Mu D, Ferriero D: Erythropoietin for neonatal brain injury: opportunity and challenge. Int J Dev Neurosci 2011;29: 583-591.

16 Fan X, van Bel F: Pharmacological neuroprotection after perinatal asphyxia. J Matern Fetal Neonatal Med 2010;23:17-19.

17 Back SA: Perinatal white matter injury: the changing spectrum of pathology and emerging insights into pathogenetic mechanisms. Ment Retard Dev Disabil Res Rev 2006;12:129-140.

18 Dammann O, Kuban KC, Leviton A: Perinatal infection, fetal inflammatory response, white matter damage, and cognitive limitations in children born preterm. Ment Retard Dev Disabil Res Rev 2002;8:46-50.

19 Mallard C, Wang X: Infection-induced vulnerability of perinatal brain injury. Neurol Res Int 2012;2012:102-153.

20 Goncalves LF, Chaiworapongsa T, Romero R: Intrauterine infection and prematurity. MRDD Res Rev 2002;8:3-13.

21 Pallast S, Arai K, Wang X, Lo EH, van Leyen $\mathrm{K}$ : 12/15-Lipoxygenase targets neuronal mitochondria under oxidative stress. J Neurochem 2009;111:882-889.

22 Li Y, Maher P, Schubert D: A role for 12-lipoxygenase in nerve cell death caused by glutathione depletion. Neuron 1997;19:453-463. 
23 Adibhatla RM, Hatcher JF, Dempsey RJ: Phospholipase $\mathrm{A}_{2}$, hydroxyl radicals, and lipid peroxidation in transient cerebral ischemia. Antioxid Redox Signal 2003;5:647-654.

-24 Rordorf G, Uemura Y, Bonventre JV: Characterization of phospholipase $\mathrm{A}_{2}\left(\mathrm{PLA}_{2}\right)$ activity in gerbil brain: enhanced activities of cytosolic, mitochondrial, and microsomal forms after ischemia and reperfusion. J Neurosci 1991; 11:1829-1836.

- 25 Kramer RM, Stephenson DT, Roberts EF, Clemens JA: Cytosolic phospholipase $\mathrm{A}_{2}$ $\left(\mathrm{cPLA}_{2}\right)$ and lipid mediator release in the brain. J Lipid Mediat Cell Signal 1996;14:3-7.

-26 Clemens JA, Stephenson DT, Smalstig EB, Roberts EF, Johnstone EM, Sharp JD, Little SP, Kramer RM: Reactive glia express cytosolic phospholipase $\mathrm{A}_{2}$ after transient global forebrain ischemia in the rat. Stroke 1996;27: 527-535.

-27 Bernaudin M, Tang Y, Reilly M, Petit E, Sharp FR: Brain genomic response following hypoxia and re-oxygenation in the neonatal rat. Identification of genes that might contribute to hypoxia-induced ischemic tolerance. J Biol Chem 2002;277:39728-39738.

28 Kuhn H, O’Donnell VB: Inflammation and immune regulation by 12/15-lipoxygenases. Prog Lipid Res 2006;45:334-356.

29 Rink C, Khanna S: Significance of brain tissue oxygenation and the arachidonic acid cascade in stroke. Antioxid Redox Signal 2011;14: 1889-1903.

- 30 Serhan CN, Brain SD, Buckley CD, Gilroy DW, Haslett C, O’Neill LA, Perretti M, Rossi AG, Wallace JL: Resolution of inflammation: state of the art, definitions and terms. FASEB J 2007;21:325-332.

-31 Serhan CN: Novel chemical mediators in the resolution of inflammation: resolvins and protectins. Anesthesiol Clin 2006;24:341364.

-32 Lukiw WJ, Cui JG, Marcheselli VL, Bodker M, Botkjaer A, Gotlinger K, Serhan CN, Bazan NG: A role for docosahexaenoic acid-derived neuroprotectin $\mathrm{D}_{1}$ in neural cell survival and Alzheimer disease. J Clin Invest 2005;115: 2774-2783.

33 Van Leyen K: Lipoxygenase: An emerging target for stroke therapy. CNS Neurol Disord Drug Targets 2013, E-pub ahead of print.

-34 Schewe T, Rapoport SM, Kuhn H: Enzymology and physiology of reticulocyte lipoxygenase: comparison with other lipoxygenases. Adv Enzymol Relat Areas Mol Biol 1986;58: 191-272.

35 Wang H, Li J, Follett PL, Zhang Y, Cotanche DA, Jensen FE, Volpe JJ, Rosenberg PA: 12-Lipoxygenase plays a key role in cell death caused by glutathione depletion and arachidonic acid in rat oligodendrocytes. Eur J Neurosci 2004;20:2049-2058.

-36 Van Leyen K, Arai K, Jin G, Kenyon V, Gerstner B, Rosenberg PA, Holman TR, Lo EH: Novel lipoxygenase inhibitors as neuroprotective reagents. J Neurosci Res 2008;86:904909.
Li J, Wang H, Rosenberg PA: Vitamin K prevents oxidative cell death by inhibiting activation of 12-lipoxygenase in developing oligodendrocytes. J Neurosci Res 2009;87:19972005.

38 Pratico D, Zhukareva V, Yao Y, Uryu K, Funk CD, Lawson JA, Trojanowski JQ, Lee VM: 12/15-Lipoxygenase is increased in Alzheimer's disease: possible involvement in brain oxidative stress. Am J Pathol 2004;164:16551662.

39 Yigitkanli K, Pekcec A, Karatas H, Pallast S, Mandeville E, Joshi N, Smirnova N, Gazaryan I, Ratan R, Witztum J, Montaner J, Holman T, Lo EH, van Leyen K: Inhibition of 12/15lipoxygenase as therapeutic strategy to treat stroke. Ann Neurol 2013;73:129-135.

40 Folkerth RD, Keefe RJ, Haynes RL, Trachtenberg FL, Volpe JJ, Kinney HC: Interferongamma expression in periventricular leukomalacia in the human brain. Brain Pathol 2004; 14:265-274.

41 Haynes RL, Folkerth RD, Trachtenberg FL, Volpe JJ, Kinney HC: Nitrosative stress and inducible nitric oxide synthase expression in periventricular leukomalacia. Acta Neuropathol 2009;118:391-399.

42 Pallast S, Arai K, Pekcec A, Yigitkanli K, Yu Z, Wang X, Lo EH, van Leyen K: Increased nuclear apoptosis-inducing factor after transient focal ischemia: a 12/15-lipoxygenase-dependent organelle damage pathway. J Cereb Blood Flow Metab 2010;30:1157-1167.

43 Back SA, Luo NL, Borenstein NS, Levine JM, Volpe JJ, Kinney HC: Late oligodendrocyte progenitors coincide with the developmental window of vulnerability for human perinatal white matter injury. J Neurosci 2001;21: 1302-1312.

44 Billiards SS, Haynes RL, Folkerth RD, Trachtenberg FL, Liu LG, Volpe JJ, Kinney HC: Development of microglia in the cerebral white matter of the human fetus and infant. J Comp Neurol 2006;497:199-208.

45 Love S, Louis DN, Ellision DW: Greenfield's Neuropathology. Oxford, Oxford University Press, 2008, vol 8.

46 Van Leyen K, Kim HY, Lee SR, Jin G, Arai K, Lo EH: Baicalein and 12/15-lipoxygenase in the ischemic brain. Stroke 2006;37:3014-3018.

-47 Nishiyama M, Watanabe T, Ueda N, Tsukamoto H, Watanabe K: Arachidonate 12-lipoxygenase is localized in neurons, glial cells, and endothelial cells of the canine brain. J Histochem Cytochem 1993;41:111-117.

48 Bendani MK, Palluy O, Cook-Moreau J, Beneytout JL, Rigaud M, Vallat JM: Localization of 12-lipoxygenase mRNA in cultured oligodendrocytes and astrocytes by in situ reverse transcriptase and polymerase chain reaction. Neurosci Lett 1995;189:159-162.

49 Sun L, Yang L, Xu YW, Liang H, Han J, Zhao RJ, Cheng Y: Neuroprotection of hydroxysafflor yellow A in the transient focal ischemia: inhibition of protein oxidation/nitration, 12/15-lipoxygenase and blood-brain barrier disruption. Brain Res 2012;1473:227-235.
50 Jin G, Arai K, Murata Y, Wang S, Stins MF, Lo $\mathrm{EH}$, van Leyen K: Protecting against cerebrovascular injury: contributions of 12/15-lipoxygenase to edema formation after transient focal ischemia. Stroke 2008;39:2538-2543.

51 Feinmark SJ, Begum R, Tsvetkov E, Goussakov I, Funk CD, Siegelbaum SA, Bolshakov VY: 12-Lipoxygenase metabolites of arachidonic acid mediate metabotropic glutamate receptor-dependent long-term depression at hippocampal CA3-CA1 synapses. J Neurosci 2003;23:11427-11435.

52 Piomelli D, Shapiro E, Feinmark SJ, Schwartz $\mathrm{JH}$ : Metabolites of arachidonic acid in the nervous system of Aplysia: possible mediators of synaptic modulation. J Neurosci 1987;7: 3675-3686.

53 Liu T, Fujita T, Nakatsuka T, Kumamoto E: Phospholipase $\mathrm{A}_{2}$ activation enhances inhibitory synaptic transmission in rat substantia gelatinosa neurons. J Neurophysiol 2008;99: 1274-1284.

54 Kinney HC: The encephalopathy of prematurity: one pediatric neuropathologist's perspective. Semin Pediatr Neurol 2009;16:179190.

55 Gerstner B, De Silva TM, Genz K, Armstrong A, Brehmer F, Neve RL, Felderhoff-Mueser U, Volpe JJ, Rosenberg PA: Hyperoxia causes maturation-dependent cell death in the developing white matter. J Neurosci 2008;28:12361245.

56 Back SA, Gan X, Li Y, Rosenberg PA, Volpe JJ: Maturation-dependent vulnerability of oligodendrocytes to oxidative stress-induced death caused by glutathione depletion. J Neurosci 1998;18:6241-6253.

57 Oka A, Belliveau MJ, Rosenberg PA, Volpe JJ: Vulnerability of oligodendroglia to glutamate: pharmacology, mechanisms, and prevention. J Neurosci 1993;13:1441-1453.

58 Yonezawa M, Back SA, Gan X, Rosenberg PA, Volpe JJ: Cystine deprivation induces oligodendroglial death: rescue by free radical scavengers and by a diffusible glial factor. J Neurochem 1996;67:566-573.

-59 Li J, Lin JC, Wang H, Peterson JW, Furie BC, Furie B, Booth SL, Volpe JJ, Rosenberg PA: Novel role of vitamin $\mathrm{K}$ in preventing oxidative injury to developing oligodendrocytes and neurons. J Neurosci 2003;23:5816-5826.

60 Deng W, Rosenberg PA, Volpe JJ, Jensen FE: Calcium-permeable AMPA/kainate receptors mediate toxicity and preconditioning by oxygen-glucose deprivation in oligodendrocyte precursors. Proc Natl Acad Sci USA 2003; 100:6801-6806.

61 Folkerth RD, Haynes RL, Borenstein NS, Belliveau RA, Trachtenberg F, Rosenberg PA, Volpe JJ, Kinney HC: Developmental lag in superoxide dismutases relative to other antioxidant enzymes in premyelinated human telencephalic white matter. J Neuropathol Exp Neurol 2004;63:990-999. 
62 Baud O, Haynes RL, Wang H, Folkerth RD, Li J, Volpe JJ, Rosenberg PA: Developmental upregulation of MnSOD in rat oligodendrocytes confers protection against oxidative injury. Eur J Neurosci 2004;20:29-40.

63 Joza N, Pospisilik JA, Hangen E, Hanada T, Modjtahedi N, Penninger JM, Kroemer G: AIF: not just an apoptosis-inducing factor. Ann NY Acad Sci 2009;1171:2-11.

64 Zhu C, Wang X, Huang Z, Qiu L, Xu F, Vahsen N, Nilsson M, Eriksson PS, Hagberg H, Culmsee C, Plesnila N, Kroemer G, Blomgren $\mathrm{K}$ : Apoptosis-inducing factor is a major contributor to neuronal loss induced by neonatal cerebral hypoxia-ischemia. Cell Death Differ 2007;14:775-784.

65 Billiards SS, Haynes RL, Folkerth RD, Borenstein NS, Trachtenberg FL, Rowitch DH, Ligon KL, Volpe JJ, Kinney HC: Myelin abnormalities without oligodendrocyte loss in periventricular leukomalacia. Brain Pathol 2008; 18:153-163.

-66 Buser JR, Maire J, Riddle A, Gong X, Nguyen T, Nelson K, Luo NL, Ren J, Struve J, Sherman LS, Miller SP, Chau V, Hendson G, Ballabh P, Grafe MR, Back SA: Arrested preoligodendrocyte maturation contributes to myelination failure in premature infants. Ann Neurol 2012;71:93-109.

-67 Segovia KN, McClure M, Moravec M, Luo NL, Wan Y, Gong X, Riddle A, Craig A, Struve J, Sherman LS, Back SA: Arrested oligodendrocyte lineage maturation in chronic perinatal white matter injury. Ann Neurol 2008;63: 520-530.

68 Czeh M, Gressens P, Kaindl AM: The yin and yang of microglia. Dev Neurosci 2011;33: 199-209.

-69 Saijo K, Glass CK: Microglial cell origin and phenotypes in health and disease. Nat Rev Immunol 2011;11:775-787.
70 Durafourt BA, Moore CS, Zammit DA, Johnson TA, Zaguia F, Guiot MC, Bar-Or A, Antel JP: Comparison of polarization properties of human adult microglia and blood-derived macrophages. Glia 2012;60:717-727.

71 Colton CA: Heterogeneity of microglial activation in the innate immune response in the brain. J Neuroimmune Pharmacol 2009;4: 399-418.

72 Khanna S, Roy S, Ryu H, Bahadduri P, Swaan PW, Ratan RR, Sen CK: Molecular basis of vitamin $\mathrm{E}$ action: tocotrienol modulates 12lipoxygenase, a key mediator of glutamateinduced neurodegeneration. J Biol Chem 2003;278:43508-43515.

73 Zhang Y, Wang H, Li J, Dong L, Xu P, Chen W, Neve RL, Volpe JJ, Rosenberg PA: Intracellular zinc release and ERK phosphorylation are required upstream of 12-lipoxygenase activation in peroxynitrite toxicity to mature rat oligodendrocytes. J Biol Chem 2006; 281:9460-9470.

74 Inder TE, Huppi PS, Warfield S, Kikinis R, Zientara GP, Barnes PD, Jolesz F, Volpe JJ: Periventricular white matter injury in the premature infant is followed by reduced cerebral cortical gray matter volume at term. Ann Neurol 1999;46:755-760.

-75 Inder TE, Warfield SK, Wang H, Huppi PS, Volpe JJ: Abnormal cerebral structure is present at term in premature infants. Pediatrics 2005;115:286-294.

76 Peterson BS, Vohr B, Staib LH, Cannistraci CJ, Dolberg A, Schneider KC, Katz KH, Westerveld M, Sparrow S, Anderson AW, Duncan CC, Makuch RW, Gore JC, Ment LR: Regional brain volume abnormalities and long-term cognitive outcome in preterm infants. JAMA 2000;284:1939-1947.

-77 Nosarti C, Al-Asady MHS, Franfou S, Stewart AL, Rifkin L, Murray RM: Adolescents who were born very preterm have decreased brain volume. Brain 2002;125:1616-1623.
78 Kesler SR, Ment LR, Vohr B, Pajot SK, Schneider KC, Katz KH, Ebbitt TB, Duncan CC, Makuch RW, Reiss AL: Volumetric analysis of regional cerebral development in preterm children. Pediatr Neurol 2004;31:318-325.

79 Peterson BS, Anderson AW, Ehrenkranz R, Staib LH, Tageldin M, Colson E, Gore JC, Duncan CC, Makuch R, Ment LR: Regional brain volumes and their later neurodevelopmental correlates in term and preterm infants. Pediatrics 2003;111:939-948

80 Folkerth RD, Trachtenberg FL, Haynes RL: Oxidative injury in the cerebral cortex and subplate neurons in periventricular leukomalacia. J Neuropathol Exp Neurol 2008;67: 677-686.

81 Boll EJ, Struve C, Sander A, Demma Z, Krogfelt KA, McCormick BA: Enteroaggregative Escherichia coli promotes transepithelial migration of neutrophils through a conserved 12-lipoxygenase pathway. Cell Microbiol 2012;14:120-132.

82 Mumy KL, Bien JD, Pazos MA, Gronert K, Hurley BP, McCormick BA: Distinct isoforms of phospholipase $\mathrm{A}_{2}$ mediate the ability of Salmonella enterica serotype typhimurium and Shigella flexneri to induce the transepithelial migration of neutrophils. Infect Immun 2008; 76:3614-3627.

83 Murphy H, Cogan T, Humphrey T: Direction of neutrophil movements by Campylobacterinfected intestinal epithelium. Microbes Infect 201;13:42-48.

-84 Wuest SJ, Crucet M, Gemperle C, Loretz C, Hersberger M: Expression and regulation of 12/15-lipoxygenases in human primary macrophages. Atherosclerosis 2012;225:121-127.

85 Middleton MK, Rubinstein T, Pure E: Cellular and molecular mechanisms of the selective regulation of IL-12 production by $12 / 15$ lipoxygenase. J Immunol 2006;176:265-274. 